\title{
Biological response modifiers in combination with antivirals against experimentally- induced virus infections
}

\author{
Robert W SidWell, PhD, JOHn H HufFMAn, PhD, DONAld F SMeE, PHD, JOHn GIlbert, MS,

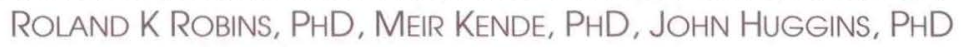

\begin{abstract}
RW Sidwell, JH HufFMAN, DF SMEE, et al. Biological response modifiers in combination with antivirals against experimentally-induced virus infections. Can J Infect Dis 1992;3(Supp1 B):49B-54B. Biological response modifiers (BRMs) have particular promise when used in combination with more standard antiviral agents for treatment of viral diseases. Reported here are a series of studies which have used two BRMs in combination with the antiviral drug, ribavirin (1- $\beta$-D-ribofuranosyl-1,2,4-triazole- 3 -carboxamide) in treatment of experimentally-induced phlebovirus (Punta Toro virus) infections in mice. The positive BRMs studied include bropirimine (2-amino-5-bromo-6-phenyl-4[3H]pyrimidinone) given orally at dosages of 25, 50 and $100 \mathrm{mg} / \mathrm{kg} /$ day beginning $24 \mathrm{~h}$ after virus inoculation, and 7-thia-8-oxoguanosine administered intraperitoneally at dosages of $6.3,12.5$ and $25 \mathrm{mg} / \mathrm{kg} /$ day given 24 and $31 \mathrm{~h}$ after virus inoculation. In each experiment, multiple dosages of both BRM and ribavirin were selected to range from ineffective levels to, in certain cases with ribavirin, lethally toxic levels. Ribavirin was always administered orally twice daily for three days starting $24 \mathrm{~h}$ after virus inoculation. Both drug combinations were considered synergistic, increasing the therapeutic index compared to either drug used alone, and significantly reducing the evidence of ribavirin toxicity. Efficacy was seen as increased survivors, decreased virus recovery from tissues and blood, and lowered glutamic oxalic and pyruvic transaminase levels in the serum.
\end{abstract}

Key Words: 7-thia-8-oxoguanosine, Antiviral, Bropirimine, Immunomodulator, Phlebovirus, Punta Toro virus, Ribavirin

\section{Modificateurs de la réponse biologique en association avec des antiviraux contre des infections virales induites expérimentalement}

Les modificateurs de la réponse biologique (MRB) sont particulièrement prometteurs lorsqu'utilisés en association avec des agents antiviraux classiques dans le traitement des maladies virales. Sont présentées ici des études au cours desquelles deux MRB ont été utilisé en association avec l'antiviral Ribavirine (1- $\beta$-D-ribofuranosyl-1,2,4-triazole-3-carboxamide) dans le traitement d'infections à phlebovirus (virus Punta Torol induites expérimentalentent chez la souris. Parmi les MRB positifs étudiés, notons la bropirimine (2-amino-5-broino-6-phényl-4[3H]pyrimidinone) administrée par voie orale à raison de 25, 50 et $100 \mathrm{mg} / \mathrm{kg} /$ jour débutant 24 heures après l'inoculation du vi,rus, et de la 7-thia-8-oxoguanosine administrée par voie intrapéritonéaley à raison de $6,3,12,5$ et $25 \mathrm{mg} / \mathrm{kg} / \mathrm{jour}, 24$ et 31 heures après l'inoculation du virus. Dans chaque expérience, des posologies multiples des deux MRB et de la Ribavirine furent sêlectionnées. Elles variaient d'inefficaces à toxiques. Elles étaient même potentiellement fatales dans certains cas avec la Ribavirine. La ribavirine a été administrée par voie orale, deux fois par jour, durant 3 jours, 24 heures après l'inoculation du virus. Les deux associations médicamenteuses furent synergiques. L'indice thérapeutique était augmenté par comparaison avec l'un ou l'autre des médiciments utilisé seul. L'on nota également une réduction significative des signes da toxicité associês à Ribavirine. Le nombre plus élevé de survivants, la quantité moindre de virus prélevée dans les tissus et le sang et des taux abaissés de transaminases glutamiques oxaliques et pyruviques sériques suggerent que le traitement était efficace.

Institute for Antiviral Research, Utah State University, Logan, Utah; Department of Pharmacology, University of California at San Diego School of Medicine, LaJolla, California; and Virus Division, US Army Medical Research Institute for Infectious Diseases, Fort Detrick, Frederick, Maryland, USA

Correspondence and reprints: Dr Robert W Sidwell, Institute for Antiviral Research, Utah State University, Logan, UT 84322-5600, USA. Telephone (801) 750-1902 
$T^{\prime}$ HE NUCLEOSIDE ANALOGUE 1- $\beta$-D-RIBOFURANOSYL-1,2,4triazole-3-carboxamide (ribavirin) is significantly inhibitory to a broad spectrum of virus infections $(1,2)$. However, ribavirin is known to be associated with various adverse effects. Toxicity, primarily manifested as anemia, is seen at doses usually only slightly exceeding those needed for therapeutic effects (3), which thus reduces the compound's therapeutic index and potential usefulness.

One approach to enhance the antiviral efficacy of ribavirin and possibly to reduce the toxicity of the drug is to use it in combination with other substances. Biological response modifiers (BRMs), by virtue of their immunomodulatory properties, appear ideal candidates for such combination chemotherapy studies. Experimental in vivo antiviral studies with combinations of other nucleoside analogues and BRMs have shown definite synergy. These positive interactions include inhibition of type 2 herpesvirus infections in mice by combinations of vidarabine and vidarabine $5^{\prime}$-monophosphate plus alpha-interferon (IFN $\alpha$ ) (4) and vidarabine plus acyclovir plus poly (ICLC) (5), and inhibition of murine retrovirus infections by $3^{\prime}$-azido- $3^{\prime}$ deoxythymidine plus IFN $\alpha$ (6). Of particular pertinence to the present manuscript is the report by Kende et al (7) which showed enhanced therapeutic efficacy against Rift Valley fever virus infections in mice using the combination of ribavirin and poly (ICLC).

This report describes the efficacy of combinations of ribavirin and two distinctly different BRMs: bropirimine (2-amino-5-bromo-6-phenyl-4[3H]pyrimidinone) and 7thia-8-oxoguanosine (TOGuo), against experimentally induced phlebovirus (Punta Toro virus [PTV]) infections of mice. Ribavirin has previously been shown to inhibit markedly the virus infection (8), and both bropirimine and TOGuo have also exerted strong activity against this virus infection when used alone (9-11).

\section{MATERIALS AND METHODS}

Virus: The Adames strain of PTV was used, which has been described previously (8). The virus was originally isolated from a patient in Panama. It was twice plaque purified, pools made, and the virus titrated in cells and in mice.

Animals: Specific pathogen-free female C57BL/6 mice weighing 10 to $12 \mathrm{~g}$ were obtained from Simonsen Laboratories (California). They were quarantined $24 \mathrm{~h}$ prior to use, housed five or 10 to a cage, and fed Wayne Laboratory Chow and tap water ad libitum.

Test compounds: Ribavirin, bropirimine and TOGuo were provided by the United States Army Medical Research Institute for Infectious Diseases. Ribavirin was prepared in sterile physiological saline. Bropirimine was suspended in $0.4 \%$ carboxymethylcellulose (CMC). TOGuo was dissolved in $2 \%$ sodium bicarbonate in water at $\mathrm{pH} 8.6$ to 8.9 .

Virus titrations: Liver homogenates (10\% weight per
TABLE 1

Treatment regimens for drug combination studies in the Punta Toro virus animal model

\begin{tabular}{llccc}
\hline Number & $\begin{array}{c}\text { Compounds } \\
\text { tested }\end{array}$ & $\begin{array}{c}\text { Treatment } \\
\text { route }\end{array}$ & $\begin{array}{c}\text { Beginning } \\
\text { of treatment }\end{array}$ & Schedule \\
\hline 1 & Ribivarin + & Oral & $+24 \mathrm{~h}$ & bid $\times 3$ \\
& bropirimine & Oral & $+24 \mathrm{~h}$ & qid $\times 3$ \\
2 & Ribivirin + & Oral & $+24 \mathrm{~h}$ & bid $\times 3$ \\
& TOGuO & IP & $+24 \mathrm{~h},+31 \mathrm{~h}$ & bid $\times 1$ \\
\hline
\end{tabular}

IP Intraperitoneal

volume) and serum were assayed for PTV titre by adding $0.1 \mathrm{~mL}$ of varying 10 -fold dilutions to triplicate cups of Rhesus monkey kidney (LLC-MK2) cell monolayers in 96-well microplates. Viral cytopathic effect was determined after six days of incubation at $37^{\circ} \mathrm{C}$, and tissue culture 50\% infective dose endpoints were determined (12).

Serum transaminase determinations: Aspartate aminotransferase (AST) and alanine aminotransferase (ALT) levels were assayed using colorimetric kits from Sigma Chemical Co (Missouri). Spectrophotometric readings for these assays were performed in duplicate using an automated microplate reader (EL309; Bio-Tek Instruments, Inc, Vermont).

Experiment design: Two objectives were sought in these studies. The first was to determine if BRMs would reduce the usual lethal or near-lethal toxicity of high doses of ribavirin. The second was to ascertain if BRMs would enhance the anti-PTV effect of inactive or marginally active doses of ribavirin. Thus, one or two usually lethal doses of ribavirin, as well as several low doses of the drug were used in these studies. Two drug combinations were studied: Ribavirin plus bropirimine, and ribavirin plus TOGuo (Table 1). Five to six experiments were run in parallel, according to the following general scheme.

Ribavirin at four or five dosages: a lethally toxic dose and three or four marginally PTV-active or inactive dosages, ie, dosages that have previously been reported (8) to have moderate to no inhibitory effects on the PTV infection. Since a variety of disease parameters were used, these dosages usually did not prevent death but may reduce AST, ALT or tissue virus titres.

- The immunomodulators bropirimine or TOGuo at three or four doses ranging from active to inactive against the PTV infection.

- Ribavirin at all doses used in the first experiment plus one of the immunomodulators used at the highest dose only.

- Ribavirin at all doses used in the first experiment plus one of the immunomodulators used at the mid-dose only.

- Ribavirin at all doses used in the first experiment plus one of the immunomodulators used at the low dose only. 
TABLE 2

Effects of combination therapy with ribavirin and bropirimine on Punta Toro virus infections in mice (combination 1)

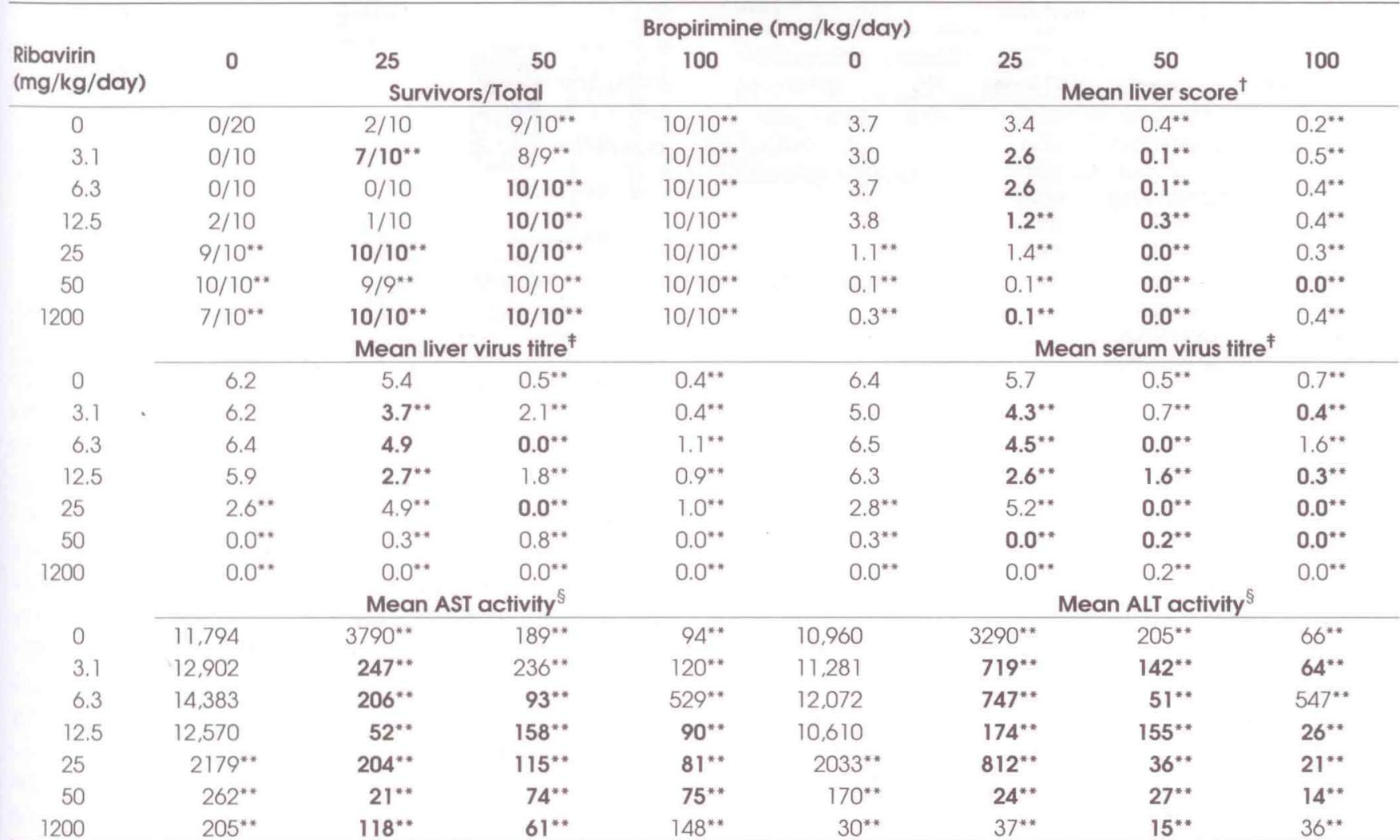

Bold-faced data indicate an improvement over either drug used alone at the dosages indicated: ${ }^{\dagger}$ Scores assigned to livers removed on day 3 post virus inoculation; ${ }^{\dagger}$ Geometric means (log $10 \mathrm{CCID} 50 / \mathrm{mL}$ ) determined on liver serum samples taken on day 3 post virus inoculation; ${ }^{5}$ Sigma-Fraenkel unilt/mL of serum samples taken on day 3 post virus inoculation; " $P<0.01$

In each experiment, 20 mice infected subcutaneously with $10^{5}$ plaque forming units (an approximately 95\% mouse lethal dose) of PTV were treated with each drug dose or one combination of each drug, and 40 infected mice were treated with the appropriate vehicle. Five sham-infected mice at each drug dosage served as toxicity controls, and 10 additional animals were used as normal controls. The uninfected, treated animals and normal controls were weighed immediately prior to initial treatment and again $18 \mathrm{~h}$ following final treatment. On infection day 3 , mice from one cage (10 animals) of each treatment group, one cage (five mice) of normal controls, and two cages of virus controls $(20$ mice) were anesthetized, bled, and their livers removed. Hepatic icterus, characterized by liver discoloration, was assigned a score of 0 (normal) to 4 (maximal discoloration). The livers were frozen at $-80^{\circ} \mathrm{C}$, and later thawed and assayed for infectious virus. The serum was frozen at $-80^{\circ} \mathrm{C}$ and later thawed and assayed for AST and ALT levels and for virus titre. Animals not killed on day 3 were observed for death through 21 days post virus inoculation.

Statistical evaluations: Survivor increases were evaluated using $\chi^{2}$ analysis with Yates' correction. Increases in mean survival time of animals dying before day 21 and reductions in AST, ALT, and virus levels in liver and serum were analyzed using the $t$ test. Liver score inhibition was compared with ranked sum analysis.

Drug combination effects were evaluated using fractional inhibitory concentration (FIC) indices as described by Berenbaum (13) to determine if the drug interactions were synergistic, additive, or antagonistic. The FIC was determined by the formula:

$$
\mathrm{FIC}=\frac{\text { MIC of drug } A \text { in combination }}{\text { MIC of drug A alone }}+\frac{\text { MIC of drug B in combination }}{\text { MIC of drug B alone }}
$$

The interpretation of the FIC values was: FIC less than 0.5 equalled synergism; FIC 0.5 to 0.9 equalled suggestive synergism; FIC approximately 1 equalled additive; FIC 1.1 to 1.9 equalled partial antagonism; FIC 2 or more equalled antagonism.

\section{RESULTS}

Ribavirin plus bropirimine: Treatment combination of ribavirin and bropirimine is summarized in Table 2 . Ribavirin was essentially inactive against the PTV infection when used at dosages of $12.5 \mathrm{mg} / \mathrm{kg} /$ day or less. Bropirimine was significantly effective at the 50 and 100 $\mathrm{mg} / \mathrm{kg} /$ day dosages. At the lowest dose, $25 \mathrm{mg} / \mathrm{kg} /$ day, only AST and ALT levels were significantly affected. Treatment with the drug combination was considered strongly synergistic using all parameters (Table 3 ). 
TABLE 3

FIC indices for drug combinations evaluated against Punta Toro virus infections in mice

\begin{tabular}{lcccc}
\hline Combination & $\begin{array}{c}\text { Evaluation } \\
\text { parameter }\end{array}$ & $\begin{array}{c}\text { FIC index } \\
\text { Survivors }\end{array}$ & $\begin{array}{c}\text { Mean } \\
\text { FIC }\end{array}$ & $\begin{array}{c}\text { Interpre- } \\
\text { tation }\end{array}$ \\
\hline 1 & Survivors & $\leq 0.6$ & Synergistic \\
Ribavirin + & Liver score & $\leq 0.6$ & & \\
bropirimine & Liver virus & $\leq 0.6$ & & \\
& Serum virus & $\leq 0.6$ & & \\
& AST & $\leq 0.6$ & & \\
2 & ALT & $\leq 0.6$ & & \\
Ribavirin + & Survivors & 1.7 & 0.6 & Synergistic \\
TOGuO & Liver score & 0.6 & & \\
& Liver virus & 0.2 & & \\
& Serum virus & 0.4 & & \\
& AST & 0.6 & & \\
\hline & ALT & 0.4 & & \\
\hline
\end{tabular}

ALT Alanine aminotransferase; AST Aspartate aminotransferase; FIC Fractional inhibitory concentration

Ribavirin's toxicity at $1200 \mathrm{mg} / \mathrm{kg} /$ day was manifested in this experiment as significant weight loss (Figure 1). When toxicity control mice were treated with both ribavirin and bropirimine, this host weight loss was not observed except at the highest dosage of bropirimine (Figure 1). In this experiment, normal controls gained $1.4 \mathrm{~g}$ during the treatment period, and toxicity control mice receiving bropirimine also gained weight as follows: $1.6 \mathrm{~g}$ at the $25 \mathrm{mg} / \mathrm{kg} /$ day dose, $0.5 \mathrm{~g}$ at the $50 \mathrm{mg} / \mathrm{kg} /$ day dose, and $2.2 \mathrm{~g}$ at the $100 \mathrm{mg} / \mathrm{kg} /$ day dose.

Ribavirin plus TOGuo: The second combination study, which used ribavirin plus TOGuo, is summarized in Table 4 . In this study, viral challenge was inadvertently

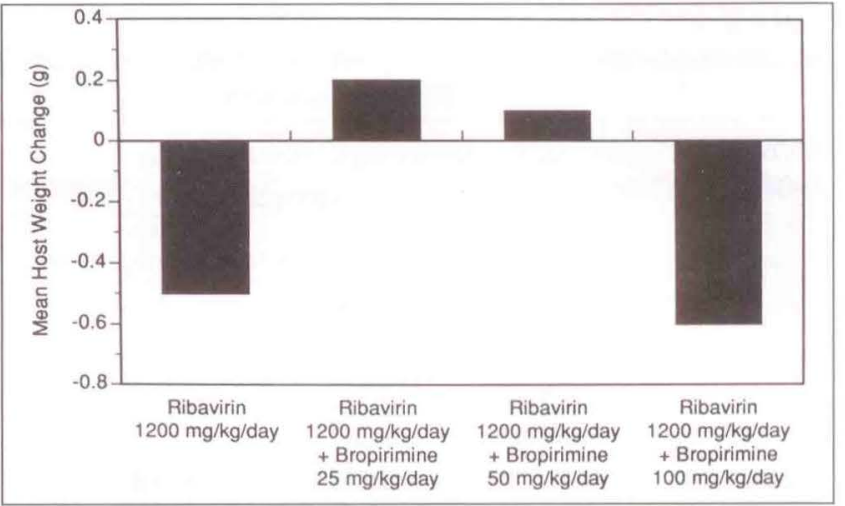

Figure 1) Effects of bropirimine treatment on ribavirin-indiced weight loss in uninfected mice

less than in the previous combination experiment. This resulted in a $25 \%$ survival occurring in the placebotreated infected mice, and the other disease parameters were somewhat reduced compared with the other studies. Antiviral effects of both ribavirin and TOGuo were readily demonstrated; with the ineffective doses of ribavirin being similar to the other experiments. TOGuo was effective using all disease parameters at the 25 $\mathrm{mg} / \mathrm{kg} /$ day dosage only; the $12.5 \mathrm{mg} / \mathrm{kg} /$ day dose significantly prevented death but was not considered significantly inhibitory to the disease using the other disease parameters. The $6.3 \mathrm{mg} / \mathrm{kg} /$ day dose of TOGuo was ineffective when used alone. Treatment with the drug combination resulted in increased disease reduction using all parameters. A calculation of FIC indices sug gested the drug combination was synergistic (Table 3).

TABLE 4

Effects of combination therapy with ribavirin and TOGuo on Punta Toro virus infections in mice (combination 2)

\begin{tabular}{|c|c|c|c|c|c|c|c|c|}
\hline \multirow{3}{*}{$\begin{array}{l}\text { Ribavirin } \\
\text { ( } \mathrm{mg} / \mathrm{kg} / \text { day) }\end{array}$} & \multicolumn{8}{|c|}{ TOGuo (mg/kg/day) } \\
\hline & 0 & 6.3 & 12.5 & 25 & 0 & 6.3 & 12.5 & 25 \\
\hline & \multicolumn{3}{|c|}{ Survivors/Total } & & & \multicolumn{3}{|c|}{ Mean liver score $^{\dagger}$} \\
\hline 6.3 & $1 / 10$ & $0 / 10$ & $9 / 10^{* *}$ & $9 / 9^{* *}$ & 2.8 & 2.3 & 0.7 & $0.7^{* *}$ \\
\hline 12.5 & $0 / 10$ & $5 / 10$ & $7 / 9^{* *}$ & $10 / 10^{* *}$ & 3.2 & 2.5 & 2.7 & $0.1^{* *}$ \\
\hline 25 & $9 / 10^{* *}$ & $10 / 10^{* *}$ & $10 / 10^{* *}$ & $10 / 10^{* *}$ & $1.4^{* *}$ & $0.5^{* * *}$ & $0.5^{* *}$ & $0.2^{* *}$ \\
\hline 0 & 3.8 & 3.4 & 2.9 & $0.0^{* *}$ & 4.1 & 4.1 & 3.1 & $0.0^{* *}$ \\
\hline 6.3 & 5.2 & 2.9 & $1.7^{*}$ & $0.3^{* *}$ & 5.9 & 3.4 & $2.4^{* *}$ & $0.4^{* *}$ \\
\hline 12.5 & 5.3 & 4.3 & 2.7 & $1.2^{* *}$ & 6.1 & 5.6 & 3.2 & $0.0^{* *}$ \\
\hline 25 & 2.4 & $0.8^{* * *}$ & $0.3^{* *}$ & $0.0^{* *}$ & $2.0^{* *}$ & $0.2^{* *}$ & $0.0^{* *}$ & $0.0^{* *}$ \\
\hline 1250 & $0.0^{* *}$ & $0.0^{* *}$ & $0.0^{* *}$ & $0.0^{* *}$ & $0.0^{* *}$ & $0.0^{* *}$ & $0.0^{* *}$ & $0.0^{* *}$ \\
\hline 12.5 & 4872 & 3270 & 708 & $199^{* *}$ & 5531 & 3925 & 609 & $153^{* *}$ \\
\hline 25 & 741 & $334^{* *}$ & $231^{* *}$ & $112^{* * *}$ & 734 & $274^{* *}$ & $159^{* *}$ & $51^{* *}$ \\
\hline 1250 & $140 * *$ & $215^{* *}$ & $260^{* *}$ & $169^{* *}$ & $25^{* *}$ & $51^{* *}$ & $51^{* *}$ & $29^{* *}$ \\
\hline
\end{tabular}

Bold-faced data indicate an improvement over either drug used alone at the dosages indicated; ${ }^{\dagger}$ Scores assigned to livers removed on day 3 post virus inoculation: ${ }^{\dagger}$ Geometric means ( $\log _{10} \mathrm{CClD} 50 / \mathrm{mL}$ ) determined on liver serum samples taken on day 3 post virus inoculation; ${ }^{\S}$ Sigma-Fraenkel unilt/mL of serum samples taken on day 3 post virus inoculation; ${ }^{*} P<0.05 ;{ }^{*} P<0.01$ 
The combination treatment also appeared to lower ribavirin's lethal toxicity, when the highest dose of TOGuo was used with the $1250 \mathrm{mg} / \mathrm{kg} /$ day dose of ribavirin (Table 5). The mice used in this experiment were approximately two days younger than those used in the bropirimine study, which may account for the apparent slight increase in ribavirin's toxic effects in this experiment.

\section{DISCUSSION}

Ribavirin is known to be immunosuppressive at high dosage levels. This has included suppression of the primary immune response in mice to sheep red blood cells (14), reduction of serum antibodies to various virus challenges (15), moderate inhibition of cellular immune response to EL-4 tumour cells (16), reduced guinea pig contact hypersensitivity to dinitrochlorobenzene (16), and inhibition of adjuvant-induced arthritis in rats (17). In contrast, the immune modulators used in this study have significant immunostimulatory properties which may be reversing ribavirin's high dosage toxicity by neutralizing the immunosuppression induced by ribavirin. It has been observed, however, in separate unpublished studies that mice dying from high dose ribavirin therapy exhibit significant bleeding into the small and large intestine. Such observations suggest an adverse effect on capillary walls which may not be related directly to the drug's immunosuppressive effects. it is not clear what role the immunomodulators used in the present study would have in reversing this capillary wall breakdown.

Bropirimine is a recognized IFN inducer (18) which has been shown previously to be active used alone against in vivo PTV infections (10). This material also activates macrophages, augments natural killer cell cytotoxicity, induces polyclonal B cell response, interleukin-1 and interleukin-2, enhances antigen-mediated antibody formation, and stimulates bone marrow proliferation (19). Pifat and Smith (20) have shown PTV to be highly sensitive to IFN induction, so it is probable that bropirimine's anti-PTV effects are primarily a result of the material's rapid IFN induction.

The anti-PTV activity of TOGuo has been described (11). This compound stimulates B cell blastogenesis, activates natural killer cells and macrophages, enhances antibody-dependent cell cytotoxicity, induces tumour necrosis factor, and induces IFN (21). Smee et al (11) have shown that the anti-PTV effects of TOGuo are completely eliminated by concomitant treatment of PTV-infected mice with anti-IFN antibody, indicating that the PTV disease inhibitory effects of this compound are also closely related to its IFN induction.

Ribavirin is currently being used clinically in the United States for treatment of severe respiratory syncytial virus infections in young children. The compound is administered in a small particle aerosol to enhance its antiviral efficacy and to lessen any potential toxic

\begin{tabular}{|c|c|c|}
\hline Drug & Dose (mg/kg/day) & Survivors (\%) \\
\hline Ribavirin & $\begin{array}{c}1250 \\
6.3 \text { to } 25\end{array}$ & $\begin{array}{c}0 \\
100\end{array}$ \\
\hline TOGuo & 6.3 to 25 & 100 \\
\hline Ribavirin + TOGuo & $\begin{array}{c}1250+6.3 \\
1250+12.5 \\
1250+25 \\
6.3 \text { to } 25+6.3 \text { to } 25\end{array}$ & $\begin{array}{c}0 \\
0 \\
80^{* *} \\
100\end{array}$ \\
\hline
\end{tabular}

" $P<0.01$ versus ribavirin alone

effects. The drug has been reported to be a strong inhibitor of phlebovirus infections such as those induced by PTV, Rift Valley fever virus and sandfly fever virus $(8,22,23)$. These infections are primarily hepatotropic, which probably require parenteral application of the drug, hence increasing the possibility of toxicological effects being manifested.

Both Rift Valley fever and sandfly fever are serious diseases of Africa and the Middle East. Severe epidemics of Rift Valley fever have been known since 1930 through much of Africa. An outbreak occurred in Sudan in 1976, with the disease apparently spreading to Egypt in the next two years with an estimated 200,000 human cases and over 600 deaths (24). During World War II, sandfly fever was a serious affliction of troops in the Mediterranean area, with 3 to $10 \%$ of all troops infected at the same time and attack rates of over $50 \%$ reported in some units (25). Both diseases are insect transmitted. PTV was used in the present studies since it is closely related to both Rift Valley fever and sandfly fever viruses, is also transmitted by biting insects, and induces a disease in mice very similar to that induced by Rift Valley fever; importantly, it causes a much less severe disease in humans (20). In addition, PTV is not readily transmitted in the laboratory. Similar sensitivities to antiviral compounds have been seen against all three viruses $(8,22,23,26)$.

These data indicate that use of immunomodulators in combination with the moderately selective antiviral drug ribavirin appear to be useful both in increasing the antiviral efficacy of all compounds employed and in lessening the toxicity of ribavirin.

ACKNOWLEDGEMENTS: This work is supported by the United States Army Medical Research Development Command under Contract No DAMD17-91- C-1030. The views, opinions and/or findings contained in this report are those of the authors and should not be construed as an official Department of the Army position, policy or decision unless so designated by other documentation. In conducting research using animals, the investigators adhered to the Guide for the Care and Use of Laboratory Animals, prepared by the Committee on Care and Use of Laboratory Animals of the Institute of of Laboratory Animal Resources, National Research Council (NIH Publication No 86-23, Revised 1985). 


\section{REFERENCES}

1. Sidwell RW, Huffman JH, Khare GP, Allen LB, Witkowski JT, Robins RK. Broad-spectrum antiviral activity of Virazole: 1- $\beta$-D-ribofuranosyl-1,2,4-triazole-3carboxamide. Science 1972;177:705-6.

2. Sidwell RW, Revankar GR, Robins RK. Ribavirin: Review of a broad-spectrum antiviral agent. In: Shugar DL, ed. International Encyclopedia of Pharmacology and Therapeutics. New York: Pergamon, 1985;2:49-107.

3. Hillyard IW. The preclinical toxicology and safety of ribavirin. In: Smith RA, Kirkpatrick W, eds. Ribavirin: A Broad Spectrum Antiviral Agent. New York: Academic 1980:59-71.

4. Crane LR, Sunstrum JC. Enhanced efficacy of nucleoside analogs and recombinant alpha interferon in weanling mice lethally infected with herpes simplex virus type 2 . Antiviral Res 1988;9:1-10.

5. Crane LR, Milne DA, Sunstrum JC, Lerner AM. Comparative activities of selected combinations of acyclovir, vidarabine, arabinosvl hypoxanthine, interferon, and polyribomosinic acid-polyribocytidylic complex against herpes simplex virus type 2 in tissue culture and intravaginally inoculated mice. Antimicrob Agents Chemother 1984; 26:557-62.

6. Ruprecht RM, Chou TC, Chipty F, Sosa MG, Mullaney S, O'Brien L, Rosas D. Interferon- $\alpha$ and 3 '-azido-3'deoxythymidine are highly synergistic in mice and prevent viremia after acute retrovirus exposure. J Acq Immunol Def Synd 1990; 3:591-600.

7. Kende M, Lupton HW, Rill WR, Levy HB, Canonico PG. Enhanced therapeutic efficacy of poly (ICLC) and ribavirin combinations against Rift Valley fever virus infections in mice. Antimicrob Agents Chemother 1987:31:986-90.

8. Sidwell RW, Huffman JH, Barnett BB, Pifat DY. In vitro and in vivo phlebovirus inhibition by ribavirin. Antimicrob Agents Chemother 1988;32:331-6.

9. Sidwell RW, Huffman JH, Barnett BB, Kende M, Pifat DY. Effects of a series of immunomodulators on experimental phlebovirus infections. Antiviral Res 1988;9:125.

10. Sidwell RW, Huffman JH, Coombs J, Renis H, Huggins J, Kende M. A comparison of pyrimidinone analogue immunomodulators for treatment of phlebovirus infections in mice. Antiviral Chem Chemother 1990;1:241-9.

11. Smee DF, Huffman JH, Gessaman A, Huggins JW, Sidwell RW. Prophylactic and therapeutic activities of 7-thia-8- oxoguanosine against Punta Toro virus infections in mice. Antiviral Res 1991;15:229-240.

12. Reed $\mathrm{L}$, Muench $\mathrm{H}$. A simple method of estimating fifty percent endpoints. Am J Hyg 1938;27:493-7.

13. Berenbaum MC. A method for testing for synergy with any number of agents. J Infect Dis 1978;137:122-130.

14. Suganuma T, Ishida N. An evaluation of a new antiviral agent, "Virazole" against influenza virus infections. Tohoku J Exp Med 1973;110:405-6.

15. Schofield KP, Potter CW, Edey D, Janning R, Oxford J. Antiviral activity of ribavirin on influenza infection in ferrets. J Antimicrob Chemother 1975; 1:63-9.

16. Sidwell RW, Ellenhorn MH, Hillyard IW, Lima JM. Safety evaluations of the broad-spectrum antiviral agent ribavirin (Virazole). In: Siegenthaler W, Luthy R, eds. Current Chemotherapy. Washington: American Society of Microbiology, 1978:335-8.

17. Kourounakis L, Young-Rodenchuk M, Kapusta MA. Virazole and adjuvant-induced disease in rats. Arth Rheum 1977;20:1032-3.

18. Nichols FR, Weed SD, Underwood GE. Stimulation of murine interferon by a substituted pyrimidine. Antimicrob Agents Chemother 1976;9:433-7.

19. Wierenga W. Antiviral and other bioactivities of pyrimidinones. Pharmacol Ther 1985;30:67-89.

20. Pifat DY, Smith JF. Punta Toro virus infection of C57BL/6j mice: A model for phlebovirus-induced disease. Microb Pathogen 1987;3:409-22.

21. Smee DF, Cottam HB, Kini GD, et al. Antiviral and immunoenhancing properties of 7-thia-8-oxoguanosine and related guanosine analogs. Can $\mathrm{J}$ Infect Dis 1992;3(Suppl B):41B-8B.

22. Stephen EL, Jones DE, Peters CJ, Eddy GA, Loinzeaux PS, Jahrling PB. Ribavirin treatment of toga-, arena- and bunyaviruses infections in subhuman primates and other laboratory animal species. In: Smith RA, Kirkpatrick W, eds. Ribavirin: A Broad Spectrum Antiviral Agent. New York: Academic Press, 1980:169-83.

23. Huggins JW, Jahrling P, Kende M, Canonico PG. Efficacy of ribavirin against virulent RNA virus infections. In: Smith RA, Knight V, Smith JAD, eds. Clinical Application of Ribavirin. New York: Academic Press, 1984:49-63.

24. Meegan JM, Watten RH, Laughlin LW. Clinical experience with Rift Valley fever in humans during the 1977 Egyptian epizootic. Conf Epidemiol Biostat 1981;3:1 14-23.

25. Oldfield EC Ill, Wallace MR, Hyams KC, Yousifi AA, Lewis DE, Bourgeois AL. Endemic infectious diseases of the middle east. Rev Inf Dis 1991;13(Suppl 3):S199-217.

26. Kende M, Lupton HW, Rill WL, Levy HB, Canonico PG. Enhanced therapeutic efficacy of poly (ICLC) and ribavirin combinations against Rift Valley fever virus infections in mice. Antimicrob Agents Chemother 1987;31:986-90. 


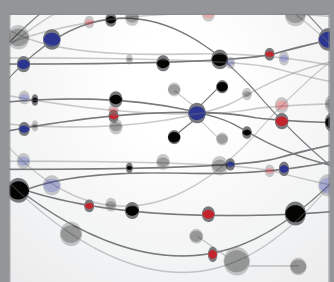

The Scientific World Journal
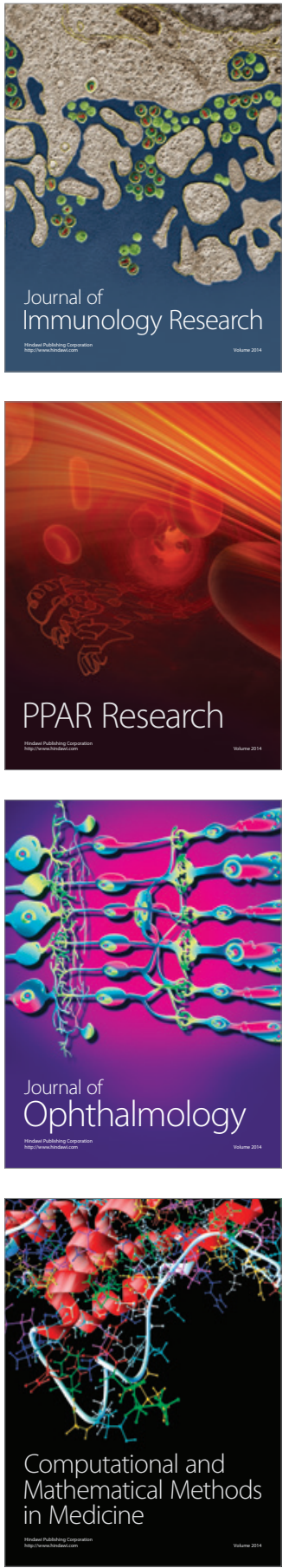

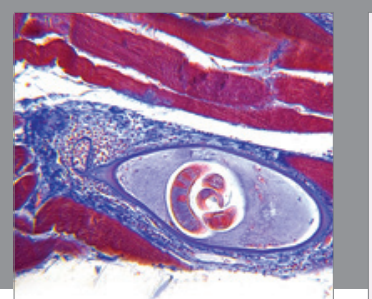

Gastroenterology Research and Practice

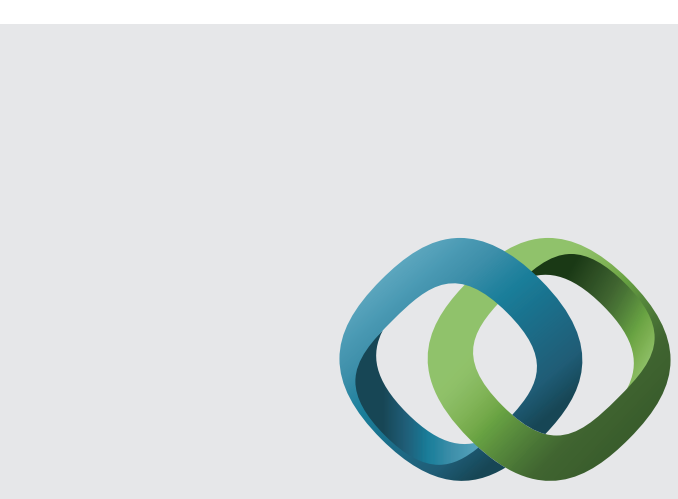

\section{Hindawi}

Submit your manuscripts at

http://www.hindawi.com
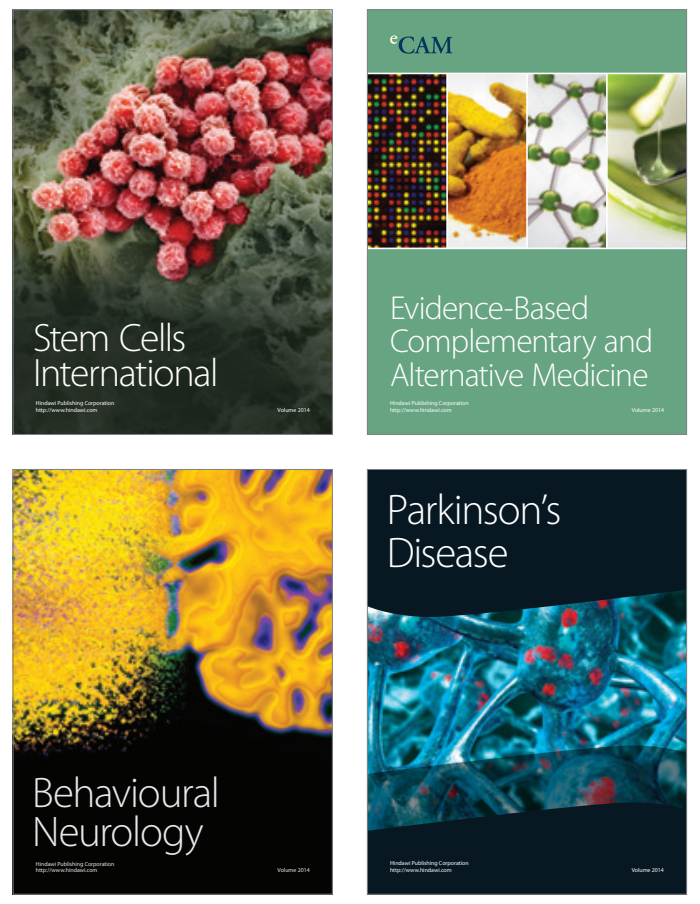
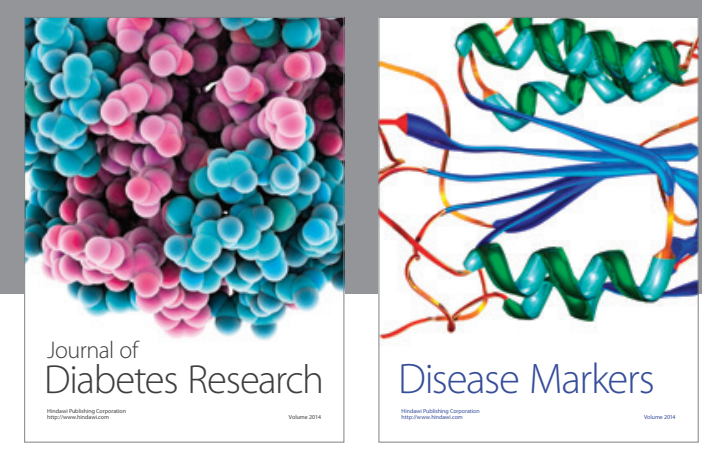

Disease Markers
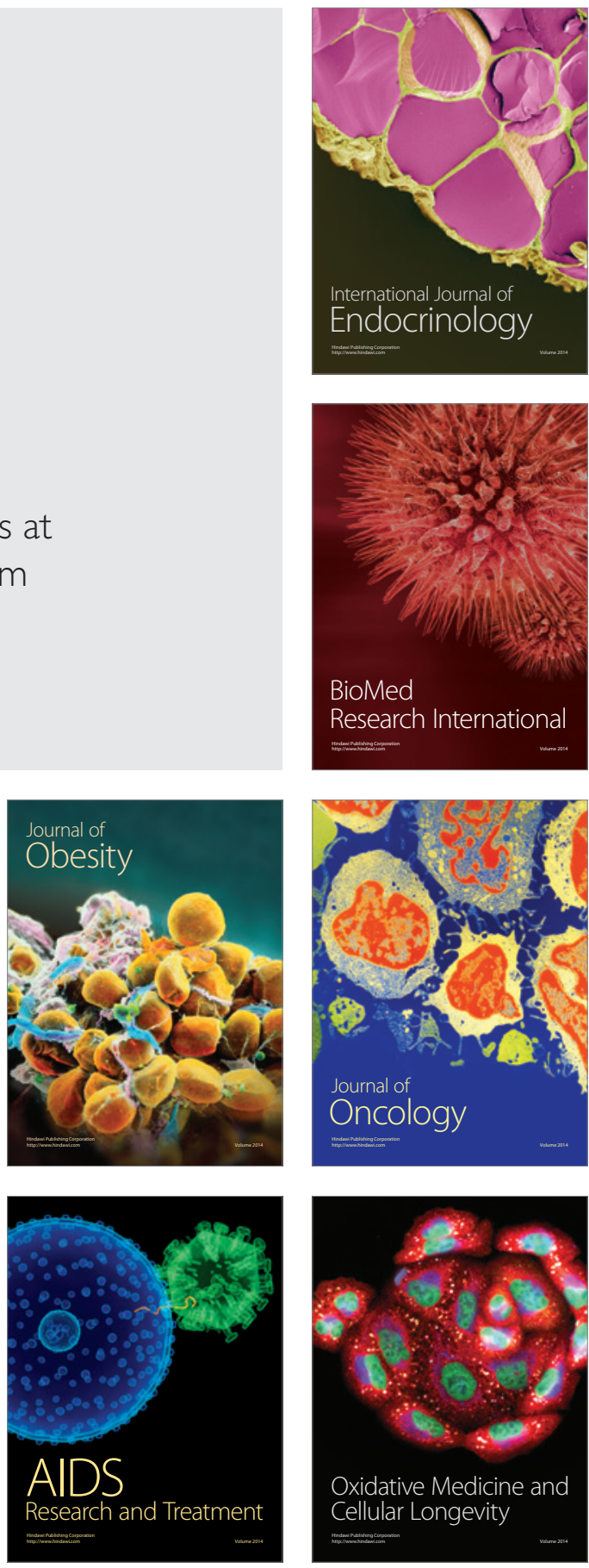